\title{
Phosphorus Recovery from Carbonized Sewage Sludge by Hydrothermal Processes
}

\author{
Masaaki Takahashi ${ }^{1 *}$,Yukimasa Takemoto ${ }^{1}$ and Ken Onishi ${ }^{2}$ \\ 1. Faculty of environmental and information science, Yokkaichi University, Yokkaichi, Mie 512-8512 Japan \\ 2. Mie Chuo Kaihatsu Co., Ltd, Hachiya4713, Iga, Mie, Japan
}

\begin{abstract}
Sewage sludge contains significant amounts of phosphorus, however, the best recovery method for them is not established. In order to establish the phosphorus recovery technique, investigation of phosphorus recovery from carbonized sewage sludge was investigated. Carbonized sewage sludge was mixed with a sodium hydroxide aqueous solution, and treated in hydrothermal conditionsfor2 to 6 hours. After this treatment, hot-water was added to the treated mixture, and phosphorus containing extract was recovered. Phosphorus was recovered as a form of sodium phosphate from phosphorus containing extract. Optimal recovery conditions were investigated in treatment temperature, amount of added $\mathrm{NaOH}$ and Solid- Liquid ratio of the charcoal and aq. NaOH solution. The recovered phosphorus was confirmed as sodium phosphate $\left(\mathrm{Na}_{3} \mathrm{PO}_{4}\right)$, and its recovering rate was estimated to be about $58 \%-71 \%$.
\end{abstract}

Key words: Carbonized sewage sludge, hydro-thermal treatment, phosphorus recovering.

\section{Introduction}

The amount of the sewage sludge is increasing due to the wide introduction of sewage systems, and most of the sewage sludge has been disposed in a landfill site as a waste. Recently, usage for cement raw material was introduced, and much of them is recycled. However, phosphorus recovering technology has not been well developed, and lot of phosphorus in the sludge is not recycled, and this important element is discharged into the environment without utilization. Japan is importing most of its phosphorus from other nations; recovery of the phosphorus has become very important matter. In order to establish the phosphorus recovering technology from sewage sludge, many studies of the chemical processes using acid [1] or alkali [2] are under way.

Recently, one of the recycle methods, carbonization techniques [3] has been introduced. Charcoal has many usages as a fuel, adsorbent, and construction materials. However, phosphorus in the sludge exists as a form of

\footnotetext{
Corresponding author: Masaaki Takahashi, lecturer, research field: environmental technique. E-mail: machaaki@amigo.ne.jp.
}

aluminum phosphate, and existence of aluminum is not good for fertilizer and makes a bad influence against other uses, therefore, removal of phosphorus becomes a very important matter.

Alkali-extraction methods can recover phosphorus as a form of alkali metal phosphate with low aluminum and heavy metal content, and are regarded as useful compared to acid extraction [4]. However, in alkali-extraction, phosphorus-extraction rate is low compared to the acid-extraction. In order to solve this problem, hydrothermal processes are considered useful compared to conventional alkali extraction [5].

Phosphorus is thought to exist mainly as a form of aluminum phosphate in the sludge. Silicon and aluminum react with alkali metal hydroxide to form zeolite, which is widely known. Based on this reaction, aluminum phosphate is expected to react with silicone components in the sludge with addition of alkali metal hydroxide under hydrothermal condition, and form alkali metal phosphate Eq. (1), and extracted from them.

Sewage sludge $\left(\mathrm{SiO}_{2}, \mathrm{AlPO}_{4}\right)+\mathrm{MOH}$

$\longrightarrow \mathrm{M}_{2} \mathrm{O} \cdot \mathrm{Al}_{2} \mathrm{O}_{3} \cdot \mathrm{xSiO}_{2}+\mathrm{M}_{3} \mathrm{PO}_{4}$ 


\section{Methods}

In this method, the charcoal of sewage sludge is mixed with alkali metal hydroxide aq. solution (as $\mathrm{NaOH}$ or $\mathrm{KOH}$ ), and treated at $70{ }^{\circ} \mathrm{C}$ to $160{ }^{\circ} \mathrm{C}$. After 2 to $6 \mathrm{~h}$ of heating, hot water $\left(90{ }^{\circ} \mathrm{C}\right)$ is added to the mixture in order to dissolve the phosphorus. Treated charcoal is separated by filtration. The extracted phosphorus (expected alkali metal phosphate) can be recovered by crystallization followed by vaporization of the filtrate $[6,7]$, as shown in Fig. 1.

In order to find the optimal recovery conditions, investigation using charcoal of the sewage sludge was carried out.

\subsection{Raw Material and Extracting Apparatus}

The experiments were carried out using the charcoal (charcoal A and charcoal B) of sewage sludge as shown in Table 1, which was made from sewage sludge by carbonization in an anaerobic chamber at $700{ }^{\circ} \mathrm{C}$

The reactor vessel (capacity:300 mL) is made of steel with a small hole in the cap [8]. The charcoal was mixed with aq. solution of sodium hydroxide, and put into the reactor vessel, heated at $70{ }^{\circ} \mathrm{C}$ to $160{ }^{\circ} \mathrm{C}$ in the heating chamber. After treatment, treated charcoal was transferred into the extracting vessel $(1,000 \mathrm{~mL})$, phosphorus was extracted by the addition of hot water, maintained at $90{ }^{\circ} \mathrm{C}$ for $10 \mathrm{~min}$ [8].

\subsection{Phosphorus Recovery Condition}

In order to determine the optimal solid-liquid mixing rate,10 $\mathrm{g}$ of carbonized sludge was mixed with an aqueous solution of sodium hydroxide (containing $6 \mathrm{~g}$ of sodium hydroxide)in some mixing rate (v/v) $1: 1$ to 1:10, and treated at $105^{\circ} \mathrm{C}$ for $6 \mathrm{~h}$. After this treatment, $100 \mathrm{~mL}$ of hot water $\left(90^{\circ} \mathrm{C}\right)$ was added to the charcoal for the phosphorus extraction, phosphorus containing filtrate and treated charcoal was separated using filter paper (No2, ADVANTEC, Tokyo Japan). In order to determine the phosphorus extraction rate, the phosphorus concentration in the filtrate was analyzed by chemical analysis, and the phosphorus extraction rate was calculated from the amount of the phosphorus dissolved in the filtrate. The highest phosphorus extraction rate was observed in mixing rate $1: 1$ as shown in Fig. 2.

In order to find out the optimal reaction temperature and alkali addition rate, experiments were carried out in the same way (mixing rate, $1: 1$, temperature, $105^{\circ} \mathrm{C}$ ). Higher phosphorus recovery rate was observed in higher alkali addition rate (Fig. 3), and also in longer heating times (Fig. 4). Phosphorus recovering rate was also investigated in the same way in some treating temperature (room temperature to $160{ }^{\circ} \mathrm{C}$ ), and higher phosphorus recovery rate was found in high heating temperatures, however, in $120{ }^{\circ} \mathrm{C}$ to $160{ }^{\circ} \mathrm{C}$, recovery rate has become almost the same(Fig. 5).From these results, the optimal phosphorus recovery conditions are regarded as shown in Table 2 [8-9].

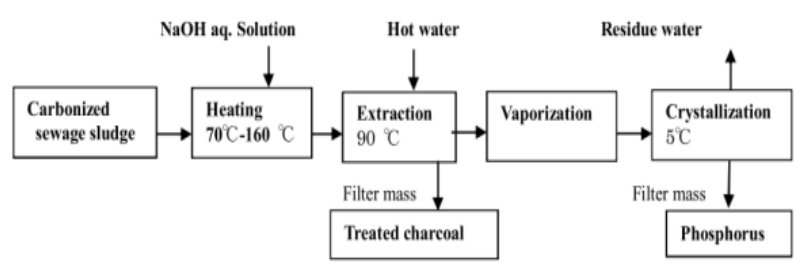

Fig. 1 Phosphorus recovery method.

Table 1 Ash composition of the charcoal in this experiment.

\begin{tabular}{lllrlll}
\hline & $\mathrm{SiO}_{2}$ & $\mathrm{Al}_{2} \mathrm{O}_{3}$ & $\mathrm{CaO}$ & $\mathrm{P}_{2} \mathrm{O}_{5}$ & $\mathrm{Fe}_{2} \mathrm{O}_{3}$ & Others \\
\hline A & 15.5 & 12.7 & 10.8 & 39.8 & 11.1 & 10.1 \\
$\mathrm{~B}$ & 27.5 & 23.1 & 6.1 & 21.8 & 11.4 & 10.1 \\
\hline
\end{tabular}

A:Charcoal A (Ash content; 62.3\%),

B: Charcoal B(Ash content; 43.8\%).

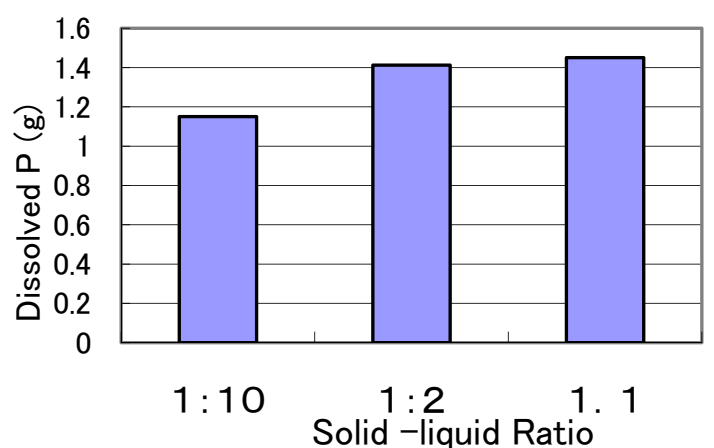

Fig. 2 Phosphorus solubility to solid-liquid ratio. (Charcoal:10 g, NaOH 6 g, Heating: $105^{\circ} \mathrm{C}, 6$ h). 


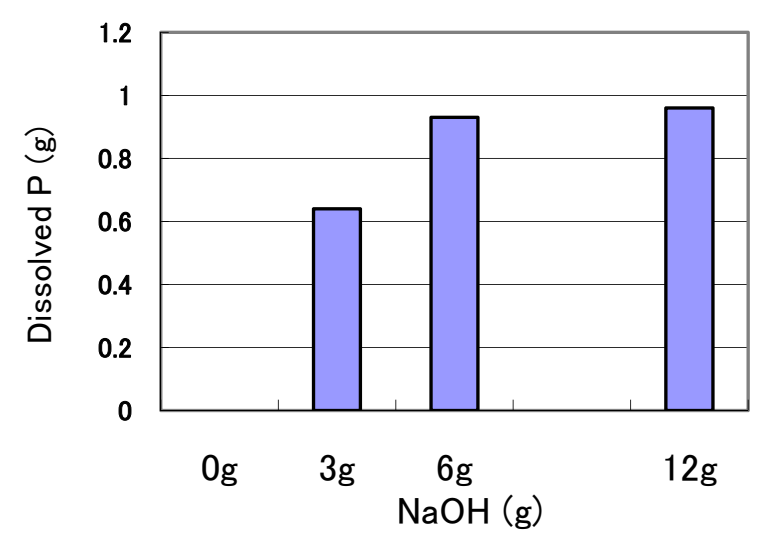

Fig. 3 Phosphorus solubility to added amount of $\mathrm{NaOH}$. (Charcoal: 10 g, Heating: $105{ }^{\circ} \mathrm{C}, 6 \mathrm{~h}$ ).

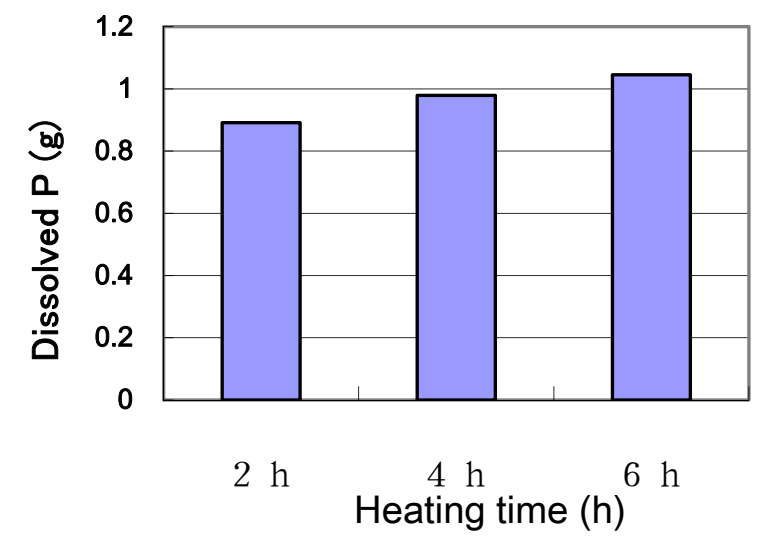

Fig. 4 Phosphorus solubility to heating time. (Charcoal: 10 g, $\mathrm{NaOH} 6$ g, Heating: $105^{\circ} \mathrm{C}$ ).

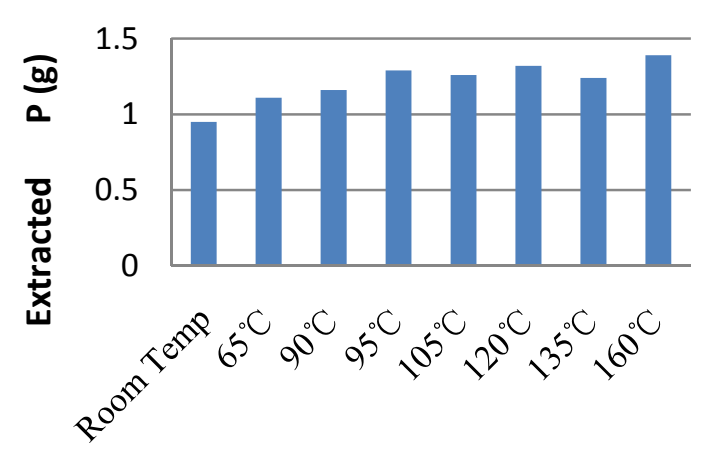

Fig. 5 Extracted phosphorus concentration to treatment. Temperature(Charcoal: 10 g, NaOH 6 g, Heating: 2 h).

Table 2 Optimal recovery condition.

\begin{tabular}{ll}
\hline Mixing rate & $\mathrm{s} / \mathrm{L}=1: 1$ \\
\hline NaOH addition rate & $\mathrm{NaOH} 6 \mathrm{~g}$ in $10 \mathrm{~g}$ of charcoal \\
Treatment temp. & $120{ }^{\circ} \mathrm{C}$ to $160{ }^{\circ} \mathrm{C}$ \\
Heating time & $2 \mathrm{~h} \mathrm{to} 6 \mathrm{~h}$ \\
\hline
\end{tabular}

\section{Results and Discussion}

\subsection{Feature of the Recovered Materials}

In order to confirm the feature of the recovered phosphorus, $50 \mathrm{~g}$ of charcoal was mixed with $\mathrm{NaOHaq}$, solution ( $\mathrm{NaOH}: 30 \mathrm{~g}+\mathrm{H}_{2} \mathrm{O} 70 \mathrm{~mL}$ ), and heated at $120{ }^{\circ} \mathrm{C}$, $2 \mathrm{~h}$ later, transferred into the vessel, extraction was carried out using $500 \mathrm{~mL}$ of water, maintained at $90{ }^{\circ} \mathrm{C}$ in 10 min followed by filtration (using filter paper as mentioned before). The filter mass was dried at $105{ }^{\circ} \mathrm{C}$, and $47 \mathrm{~g}$ of treated charcoal was recovered. The filtrate (500 mL) was concentrated to $150 \mathrm{~mL}$ by evaporation, and cooled at $5{ }^{\circ} \mathrm{C}$ in an icebox, $34 \mathrm{~g}$ of phosphorus was recovered from the concentrated filtrate by crystallization. Residue water (70 mL) which remained after crystallization was dried at $105{ }^{\circ} \mathrm{C}$, and $13 \mathrm{~g}$ of salt was recovered. The salt was estimated to contain about $10 \mathrm{~g}$ of $\mathrm{NaOH}$ by chemical analysis.

The appearance of the treated charcoal is black grain, and no-apparent change in its features was found. However, ash content and specific gravity was decreased compared to non-treated charcoal by the elution of ash components as shown in Table 4.

The treated charcoal was incinerated at $600{ }^{\circ} \mathrm{C}$, and the recovered phosphorus was dried at $105{ }^{\circ} \mathrm{C}$ for analysis. Incinerated ash and recovered phosphorus were analyzed using XRF (Rigaku Corporation SPECTRO XEPOS).

The ash of the treated charcoal was mainly composed of $\mathrm{SiO}_{2}, \mathrm{Al}_{2} \mathrm{O}_{3}$ and $\mathrm{Na}_{2} \mathrm{O}$ as shown in Fig. 6 and Fig. 7. The amount of the phosphorus in the charcoal

Table 3 Amount of recovered material.

\begin{tabular}{llll}
\hline $\begin{array}{l}\text { Raw } \\
\text { charcoal(A) }\end{array}$ & $\begin{array}{l}\text { Treated } \\
\text { charcoal }\end{array}$ & $\begin{array}{l}\text { Recovered } \\
\text { phosphorus }\end{array}$ & $\begin{array}{l}\text { Salt in the } \\
\text { residue water }\end{array}$ \\
\hline $50 \mathrm{~g}$ & $47 \mathrm{~g}$ & $34 \mathrm{~g}$ & $13 \mathrm{~g}$ \\
\hline
\end{tabular}

Table 4 Feature of the treated charcoal.

\begin{tabular}{llll}
\hline & Appearance & $\begin{array}{l}\text { Specific } \\
\text { gravity }\end{array}$ & $\begin{array}{l}\text { Ash } \\
\text { content }\end{array}$ \\
\hline Raw charcoal A & Black grain & - & $62.3(\%)$ \\
Treated charcoal A & Black grain & - & $56.2(\%)$ \\
Raw charcoal B & Black grain & 0.41 & $43.8(\%)$ \\
Treated charcoal B & Black grain & 0.38 & $38.7(\%)$ \\
\hline
\end{tabular}




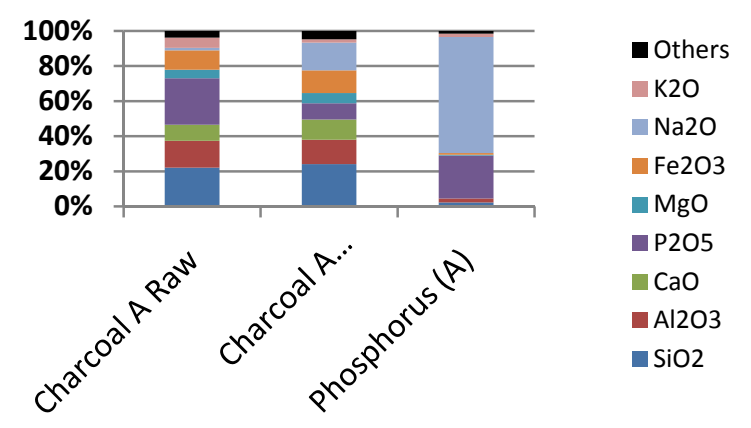

Fig. 6 Composition of recovered materials (charcoal A).

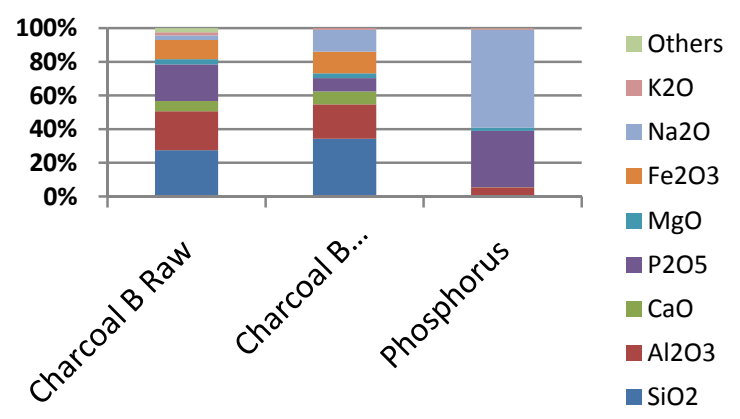

Fig. 7 Composition of recovered materials (charcoal B).

was decreased by the phosphorus removal. Phosphorus components in the charcoal are inconvenient for usage as a raw material of cement or iron reducing agent. The charcoal treated by this method has lower concentrations of phosphorus, and is regarded more useful compared to a non-treated one because of its lower phosphorus concentration and also ash content. However, significant amounts of non-reacted $\mathrm{P}_{2} \mathrm{O}_{5}$ remained in the treated charcoal, and much more effort to attain higher recovery rate is needed. $\mathrm{CaO}$ and $\mathrm{Fe}_{2} \mathrm{O}_{3}$ component in the charcoal were relatively increased by the treatment because of elution of the phosphorus. $\mathrm{Na}_{2} \mathrm{O}$ content increased, which remained with residue water in the charcoal, or any reaction of $\mathrm{NaOH}$ and ash components in the charcoal.

The recovered phosphorus is mainly composed of $\mathrm{Na}_{2} \mathrm{O}$ and $\mathrm{P}_{2} \mathrm{O}_{5}$, and a small amount of $\mathrm{Al}_{2} \mathrm{O}_{3}$. Recovered phosphorus is considered mainly composed of sodium phosphate $\left(\mathrm{Na}_{3} \mathrm{PO}_{4} \cdot 12 \mathrm{H}_{2} \mathrm{O}\right)$ from this chemical composition and $\mathrm{X}$-ray diffraction analysis (Rigaku Corporation) shown in Fig. 8.

\subsection{Phosphorus Recovery Rate}

The phosphorus recovery rate was calculated as follows (Eq. (2)). Phosphorus recovery rate was estimated to be $58 \%$ to $71 \%$ (charcoal A and charcoal B)

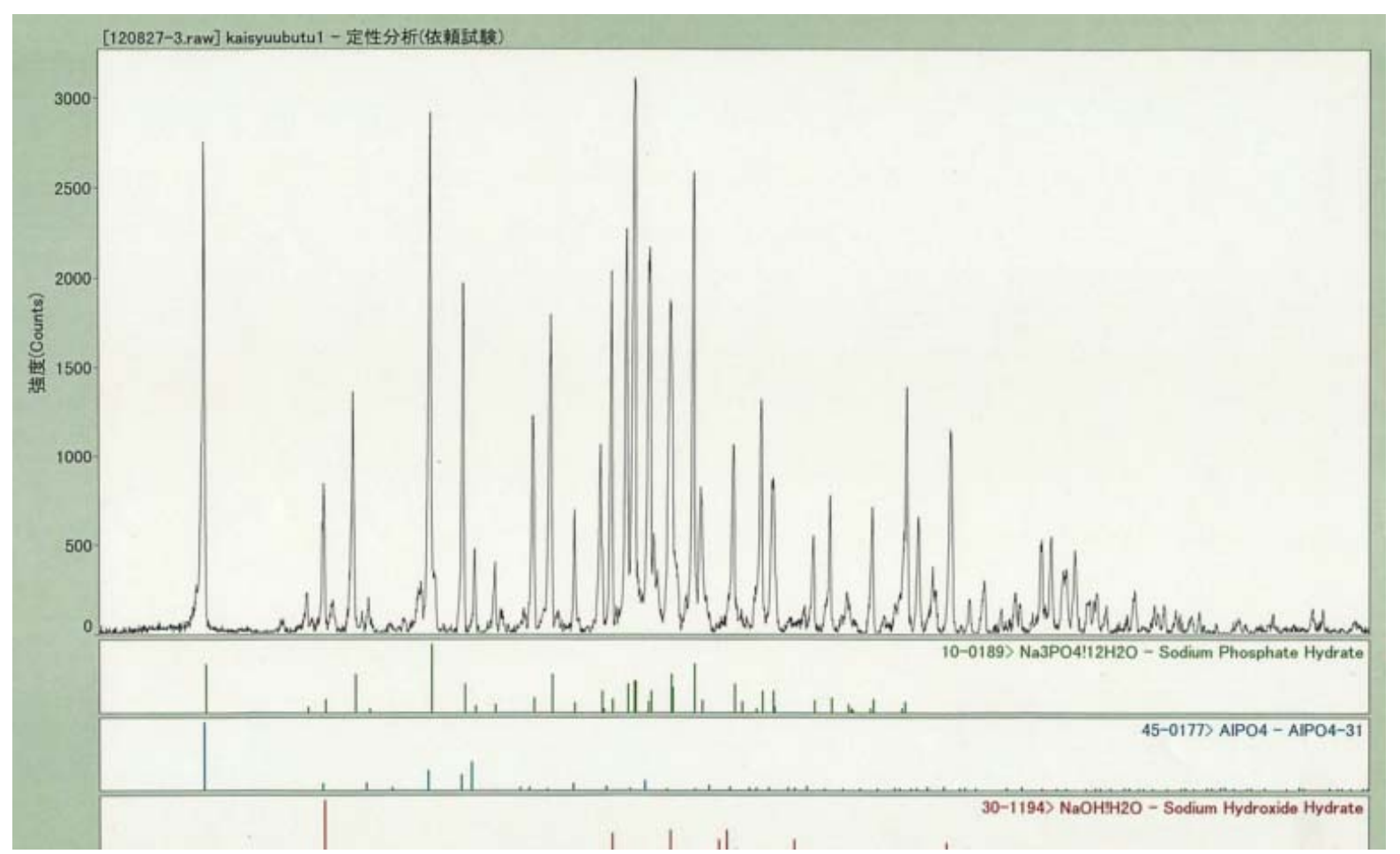

Fig. 8 XRD of the recovered phosphorus (A). 
from the chemical analysis [9].

$$
\mathrm{P}(\%)=(\mathrm{P} 1 \times \mathrm{A} 1-\mathrm{P} 2 \times \mathrm{A} 2) \div \mathrm{P} 1 \times \mathrm{A} 1 \times 100
$$

Ash content of the non-treated charcoal:A1 (\%);

Ash content of the treated charcoal:A2 (\%);

Phosphorus content in the non-treated charcoal:P1

(P g/g ash);

Phosphorus content in the treated charcoal:P2 (P g/g ash).

\section{Conclusions}

In order to find the best way of phosphorus recovery from charcoal of sewage sludge, a hydro-thermal method using sodium hydroxide was investigated. Phosphorus was successfully recovered from the charcoal of sewage sludge by hydrothermal treatment, and its optimal recovering condition was investigated, and the recovery rate was estimated to be $58 \%-71 \%$.

Phosphorus was recovered as a form of $\mathrm{Na}_{3} \mathrm{PO}_{4}$ by this method. $\mathrm{Na}_{3} \mathrm{PO}_{4}$ is dissolves in water, therefore purification is easy through crystallization processes.

However some studies are needed:

(1) More higher recovery rate is needed;

(2) In order to crystalize phosphorus, enrichment of phosphorus in the extract is important, and concentration method using less energy consumption is recommended;

(3) Residue water which remains after phosphorus recovering, contains significant amount of no-reacted alkali, reuse of this alkali is also needed.

In order to solve these matters, some studies are now being carried out [10].

\section{References}

[1] Takahashi, M., Kato, S., Shima, H., Sarai, E., Ichioka, T., Hayakawa, S., and et al.. 2001. "Technology for Recovering Phosphorus from Incinerated Wastewater
Treatment Sludge.” Chemosphere 44: 23-9.

[2] Yoshida, K., Takahashi, Y., and Hatano, M. 2001. “The Experiment on the Recovering of SOdium Phosphate from Incinerated Ash of Sewage Sludge.” In Proceedings of the 12th Annual Conference of the Japan Society of Waste Management Experts, 280-2. (in Japanese)

[3] Hinata, H., Uchino, K., Yasui, T., and Saito, T. 1996. "Utilization of Sewage Sludge as Form of Active Carbon." In Proceedings of the $7^{\text {th }}$ annual conference of the Japan society of waste management expert, 6-16: 288-290. (in Japanese)

[4] Takahashi, Y., Yosida, K., Hatano, M. 2001. “The Experiment on the Recovering of Calcium Phosphate from Incinerated Ash of Sewage Sludge.” In Proceedings of the 12th Annual Conference of the Japan Society of Waste Management Experts, 280-282. (in Japanese)

[5] Sato, K., Takahashi, M., Onari, Y., Kato, S., and Enjyoji, H. 2004. "A Technique for REcovering Sodium Phosphate from Sewage Treatment Sludge by Hydrothermal Synthesis.” Transactions of Materials Research Society of Japan 29 (5): 2021-4.

[6] Takahashi, M., Sato, K., Kato, S., and Enjyoji, H. 2007. "Technique for Recovering Phosphorus from Sewage Sludge." In Proceedings of the 8th International Conference on Ecomaterials, 2: 389-395.

[7] Takahashi, M., and Takemoto, Y. 2009. "Phosphorus Recovering from Carbonized Sewage Sludge Using Hydrothermal Processes.” In Proceedings of 20th Annual Conference of Japanese Society of Material Cycles and Waste Management, 2009, 323-4. (in Japanese)

[8] Takahashi, M., and Takemoto, Y. 2010. "Phosphorus Recovering from Carbonized Sewage Sludge by Hydrothermal Processes." In Proceedings of 9th International Conference on Eco Balance, 27.

[9] Takahashi, M., Takemoto, Y., and Onishi, K. 2013. "Phosphorus Recovering Conditions from Carbonized Sewage Sludge Using Hydrothermal Processes." Yokkaichi University Journal of Environmental and Information Science16 (2): 39-49. (in Japanese)

[10] Takahashi, M., Takemoto, Y., and Oonishi, K. 2013. "Phosphorus Recovery from Charcoal of Sewage Sludge Using NaOH.” International Journal for Sustainable Innovations3 (1): 37-44. 